\title{
Rancang Bangun Penstabil Tegangan pada Pembangkit Termoelektrik Skala Pico Berbasis Boost Converter
}

\author{
Ailin Rohmatul Fajria ${ }^{* 1}$, Budhi Priyanto ${ }^{2}$, Ilham Pakaya ${ }^{3}$, Zulfatman ${ }^{4}$ \\ $1,2,3,4$ Universitas Muhammadiyah Malang \\ ailinfajriar99@gmail.com*1, budhi67@gmail.com², ilhampakaya@gmail.com³ \\ zulfatman78@gmail.com ${ }^{4}$
}

\begin{abstract}
Abstrak
Kurangnya pemanfaatan modul termoelektrik sebagai pembangkit listrik di masyarakat sering diakibatkan energi yang dihasilkan cenderung tidak stabil. Sehingga diperlukan sebuah rangkaian penstabil tegangan yang dapat menaik dan menurunkan tegangan menjadi tegangan tertentu. Tujuan proyek ini adalah merancang sebuah rangkaian penstabil tegangan DC skala pico berbasis boost converter. Pengujian dilakukan dengan 3 tahap, yaitu pengujian rangkaian penstabil menggunakan sumber adaptor yang mempunyai tegangan masukan 3-9 V, pengujian kinerja pembangkit termoelektrik pada beberapa $\Delta T$ tertentu dan pengujian rangkaian penstabil menggunakan sumber termoelektrik dengan $\Delta T$ yang sama dengan pengujian sebelumnya. Hasil pengujian pertama, saat diberikan tegangan masukan 3 hingga $9 \mathrm{~V}$ maka menghasilkan tegangan keluaran 5,07 hingga 5,08 V sehingga memiliki persentase ketepatan 98,55\% terhadap tegangan $5 V$ yang diharapkan. Pada pengujian kedua, yaitu saat $\Delta T$ bernilai 30,50 dan $70{ }^{\circ} \mathrm{C}$ menghasilkan tegangan keluaran 2,5, 3,04 dan 3,39 V. Sementara pada pengujian ketiga dengan $\Delta T$ yang sama menghasilkan tegangan keluaran 5,08 hingga 5,09 V. Namun, saat $\Delta T$ bernilai $12{ }^{\circ} \mathrm{C}$ mengeluarkan tegangan 0,8 hingga $0,9 \mathrm{~V}$ baik pada pengujian kedua maupun ketiga, hal ini disebabkan tidak memenuhi tegangan kerja sistem penstabil yaitu 2 hingga $24 \mathrm{~V}$. Hubungan antara $\Delta T$ terhadap Tegangan Keluaran (V), Arus (I) dan Daya $(P)$ yang dihasilkan memiliki nilai $R$ positif 0,76 hingga 1, yang berarti adanya hubungan berbanding lurus. Sehingga, semakin besar nilai $\Delta T$ maka akan berdampak pula pada semakin besarnya nilai $V$, I dan $P$ yang dapat menjadi indikator kualitas pembangkit termoelektrik yang sedang diuji.
\end{abstract}

Kata kunci: Termoelektrik, Boost Converter

\section{Abstract}

Least of using thermoelectric module as an electric generator in society was often because of energy which was produced by it was unstable. So we need voltage stabilizer circuit to push up and down the voltage to certain voltage. The purpose of this project is to design a voltage stabilizer circuit in pico scale DC voltage based on boost converter. This experiment is done by three stage there are, stabilizer experiment by adapto with input voltage 3-9, performance of thermoelectric generator in several $\Delta T$ and also stabilizer experiment by thermoelectric generator in the same $\Delta T$ which done in second experiment. The yield of the first experiment, when we gave input voltage 3 until $9 \mathrm{~V}$ produced 5,07 until 5,08 V, so it has 98,55\% accuracy toward $5 \mathrm{~V}$ expect. On the second experiment, when it is given by $\Delta T 30,50$ and $70^{\circ} \mathrm{C}$ produced 2,5, 3,04 and 3,39 V. While on third experiment, with the same $\Delta T$ produced 5,08 until 5, $09 \mathrm{~V}$. But, when $\Delta T$ which given by $12{ }^{\circ} \mathrm{C}$ produced only 0,8 and $0,9 \mathrm{~V}$ in second and third experiment, it is because of the voltage is not fulfill accupation voltage 2 until $24 \mathrm{~V}$ on datasheet of used IC. Relation between $\Delta T$ and Voltage $(V)$, Current $(I)$ also Power $(P)$ which was produced have positive $R$ value 0,76 until 1 , this mean that $\Delta T$ directly proportional to $V, I$ and $P$. So, the higher $\Delta T$ we give, the higher $V, I$ and $P$ will be a quality indicator for a thermoelectric generator.

Keywords: Stabilizer, Boost Converter

\section{Pendahuluan}

Saat ini energi listrik sudah menjadi kebutuhan primer bagi masyarakat baik yang hidup di perkotaan maupun di pelosok pedesaan. Peningkatan kebutuhan energi listrik yang tinggi 
membuat kehadiran alternatif energi baru semakin dibutuhkan, yang ramah lingkungan dan dapat diperbaharui. Energi termal merupakan salah satu sumber yang tidak terbatas dan mudah ditemui [1]. Pemanfaatannya dapat melalui suatu alat yang dapat mengonversi energi panas menjadi energi listrik, yaitu dengan modul termoelektrik [2] [3]. Kurangnya pemanfaatan modul termoelektrik sebagai pembangkit listrik skala kecil di masyarakat sering diakibatkan karena energi yang dihasilkan oleh sekeping modul termoelektrik cenderung kecil dan keluarannya tidak stabil atau berfluktuasi. Untuk mengatasi hal tersebut, diperlukan sebuah rangkaian penstabil tegangan DC skala pico berbasis boost converter yang dapat membuat tegangan keluaran dari modul termoelektrik menjadi stabil pada $5 \mathrm{~V}$.

Modul termoelektrik TEC12706 dapat dimaksimalkan kegunaannya, karena ketersediaan dan harganya yang relatif murah untuk dijadikan sebagai pembangkit listrik skala pico [4]. Perangkaiannya dapat dilakukan dengan cara seri dan paralel [5]. Berdasarkan sifat-sifat yang dimiliki dan kegunaannya, modul termoelektrik dibagi menjadi dua jenis, yaitu termoelektrik sebagai pendingin (cooler) dan sebagai generator [6], dimana proses kerjanya menggunakan efek Peltier untuk membuat aliran panas (heat-flux) pada percabangan antara dua jenis material yang berbeda [7]. Konsep Seebeck sebagai efek dari dua buah material logam yang tersambung berada di lingkungan dengan dua temperatur berbeda, maka pada material tersebut akan mengalir arus listrik atau gaya gerak listrik [8]. Energi termal atau panas ini mengalir dari benda satu ke benda lainnya karena perbedaan suhu panas ke suhu dingin [9]. Efek ini menyatakan bahwa terdapat penyerapan atau pelepasan panas bolak-balik dalam konduktor homogen yang terkena perbedaan suhu panas dan perbedaan listrik secara simultan [10]. Beberapa komponen elektronika yang dapat digunakan adalah IC SDB6285 yang memiliki frekuensi yang konstan, dapat mengubah pulsa modulasi frekuensi secara otomatis, dengan fitur under-voltage lockout yang berarti tidak dapat bekerja pada tegangan minimal $2 \mathrm{~V}$ dan maksimal $24 \mathrm{~V}$, serta mampu menghasilkan tegangan keluaran hingga $28 \mathrm{~V}$. Untuk menyimpan energi listrik yang dihasilkan, dibutuhkan IC battery charging TP4056 yang dapat bekerja pada tegangan 4 hingga 8 V. Untuk dapat menaikkan tegangan diperlukan sistem boost converter yang sudah tertanam pada fungsi IC SDB6285, tetapi jika tegangan masukan lebih dari $5 \mathrm{~V}$ juga dapat diturunkan dengan sistem sederhana pembagi tegangan. Penggunaan penarik dan penurun tegangan ini masih jarang ditemui, apalagi yang digunakan pada pembangkit skala pico. Maka, perancangan rangkaian penstabil tegangan DC skala pico dirasa perlu dilakukan guna memaksimalkan pemanfaatan alternatif sumber energi listrik.

\section{Metode Penelitian}

Pertama yang harus disiapkan adalah rangkaian 8 buah modul termoelektrik tipe TEC112706 yang disusun secara seri dan paralel agar dapat mempertinggi tegangan dan arus seperti yang dapat dilihat dalam Gambar 1.

Kemudian pada proses pendesainan rangkaian penstabil dan rangkaian charging baterai sebagai rangkaian pengisi daya baterai dari sumber modul termoelektrik. Dalam Gambar 2 akan diperlihatkan desain rangkaian gabungan penstabil menggunakan dua buah IC B6285 dan charging menggunakan IC TP4056.

Setelah proses perancangan, dilanjutkan pada proses pengujian alat dan pengambilan data. Pengujian rangkaian penstabil dilakukan dengan menggunakan dua media sumber listrik, yaitu dengan adaptor dan pembangkit termoelektrik. Pengujian pertama menggunakan adaptor yang dapat dirubah-ubah tegangannya, sebagai pengujian rangkaian penstabil dapat menghasilkan tegangan keluaran $5 \mathrm{~V}$, meskipun tegangan masukannya berada dibawah maupun diatasnya. Teknik pengujian menggunakan adaptor dengan merubah 5 variabel nilai masukan sumber tegangan terhadap rangkaian penstabil dan melihat apakah tegangan keluaran yang dihasilkan rangkaian penstabil adalah $5 \mathrm{~V}$.

Pengujian kedua dilakukan dengan mengukur tegangan dan arus keluaran yang dihasilkan pembangkit termoelektrik tanpa menggunakan penstabil. Pengujian ketiga dilakukan dengan mengukur tegangan dan arus keluaran saat menggunakan penstabil tegangan. Pengujian kedua dan ketiga dilakukan untuk membandingkan nilai tegangan keluaran saat belum dan setelah menggunakan rangkaian penstabil, sehingga dapat diketahui seberapa besar pengaruh rangkaian penstabil yang telah didesain.

Pada saat menggunakan sumber pembangkit termoelektrik, kita harus meletakkan beberapa buah api pembakaran minyak tanah di bawah tungku pemanas untuk menyimulasikan panas dan mengisi kotak pendingin dengan es. Penambahan es akan dilakukan untuk menjaga

KINETIK Vol. 2, No. 2, Mei 2017: 117-124 
kestabilan temperatur dingin. Api diletakkan di bawah tungku pemanas dengan jarak $2 \mathrm{~cm}$ antara panas api dengan plat besi yang menghantarkan panas pada sisi panas modul termoelektrik. Setiap kenaikan $5^{\circ} \mathrm{C}$ pada suhu pemanas akan dilakukan pengukuran tegangan keluaran.

Pengambilan data akan dilakukan sebanyak 23 kali, 3 kali pada saat menggunakan sumber adaptor, 10 kali pada rangkaian tanpa penstabil dan 10 kali dengan menggunakan penstabil. Data diambil secara manual dengan cara mengukur tegangan dan arus keluaran menggunakan multimeter. Dengan mengambil data tegangan keluaran ini bertujuan untuk mengetahui apakah penstabil sudah berfungsi dengan baik atau belum. Pencatatan data dilakukan untuk mengetahui bagaimana pengaruh rangkaian penstabil pada perancangan alat, apakah dapat berfungsi sesuai dengan yang diharapkan atau tidak.

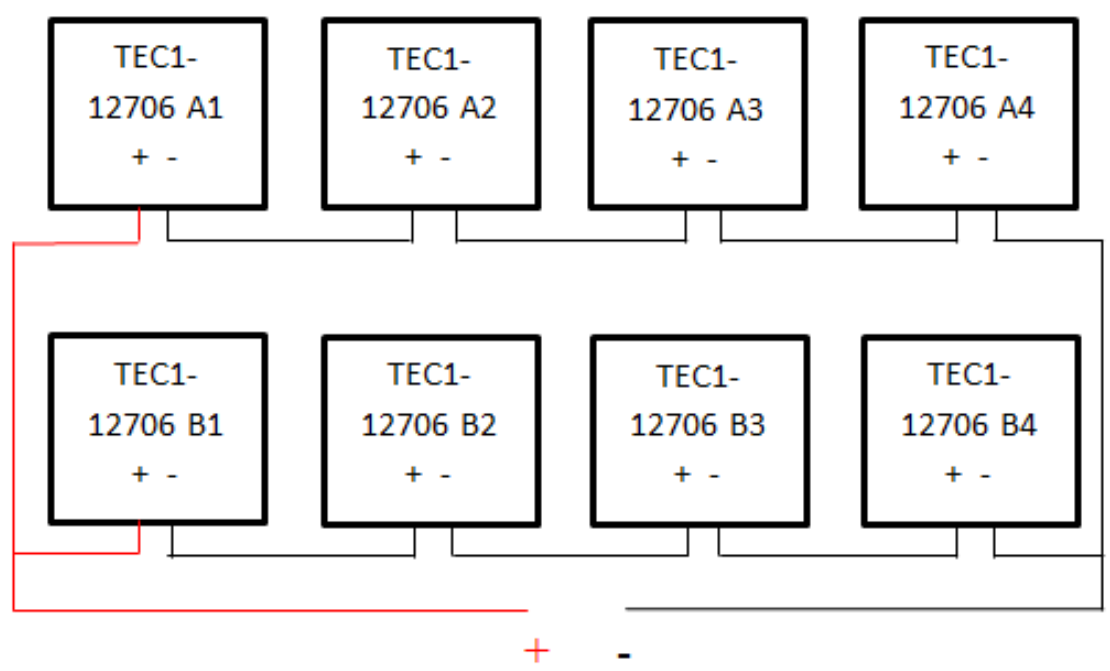

Gambar 1. Penyusunan dan Perangkaian Modul Termoelektrik

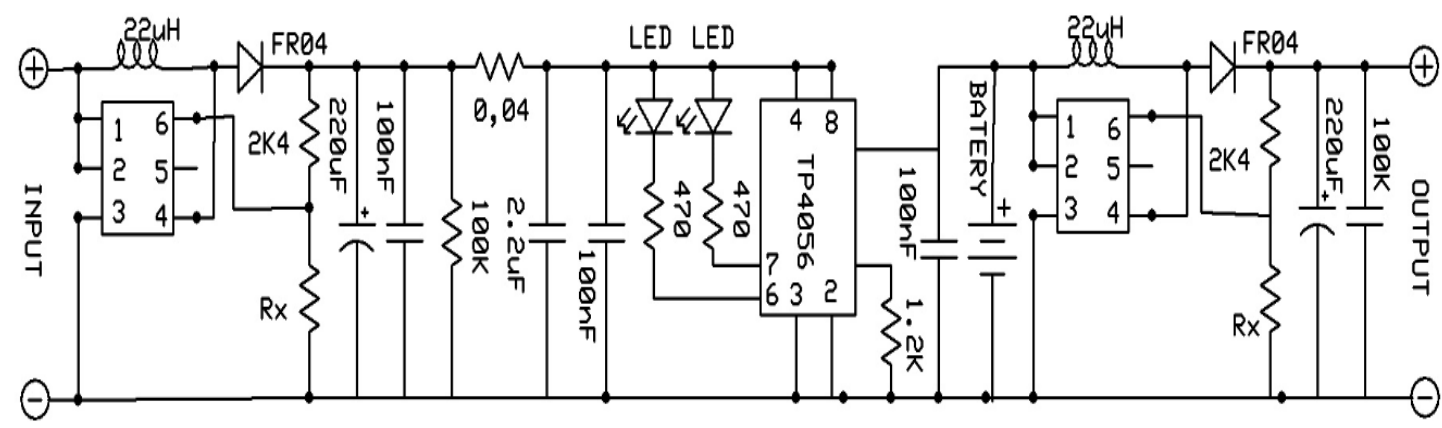

Gambar 2. Rangkaian Penstabil Tegangan DC Berbasis Boost Converter

\section{Hasil Penelitian dan Pembahasan}

\subsection{Pengujian Rangkaian Penstabil Menggunakan Sumber Adaptor}

Dalam Tabel 1, Gambar 3 dan Gambar 4 dapat kita lihat data hasil pengujian rangkaian penstabil saat menggunakan sumber tegangan adaptor. Nilai tegangan masukan yang berada dibawah maupun diatas tegangan $5 \mathrm{~V}$ akan dikonversi hingga bernilai $5 \mathrm{~V}$. Peningkatan besar tegangan masukan ini berbanding lurus dengan besar arus yang dihasilkan.

Tabel 1. Data Hasil Pengujian Rangkaian Penstabil Menggunakan Adaptor

\begin{tabular}{cccc}
\hline No & V Input $(\mathrm{V})$ & V Output $(\mathrm{V})$ & I Output $(\mathrm{mA})$ \\
\hline 1 & 3 & 5,07 & 1,5 \\
\hline 2 & 4,5 & 5,07 & 26,7 \\
\hline 3 & 6 & 5,07 & 42,8 \\
\hline 4 & 7,5 & 5,08 & 47,2 \\
\hline 5 & 9 & 5,08 & 50,1 \\
\hline
\end{tabular}




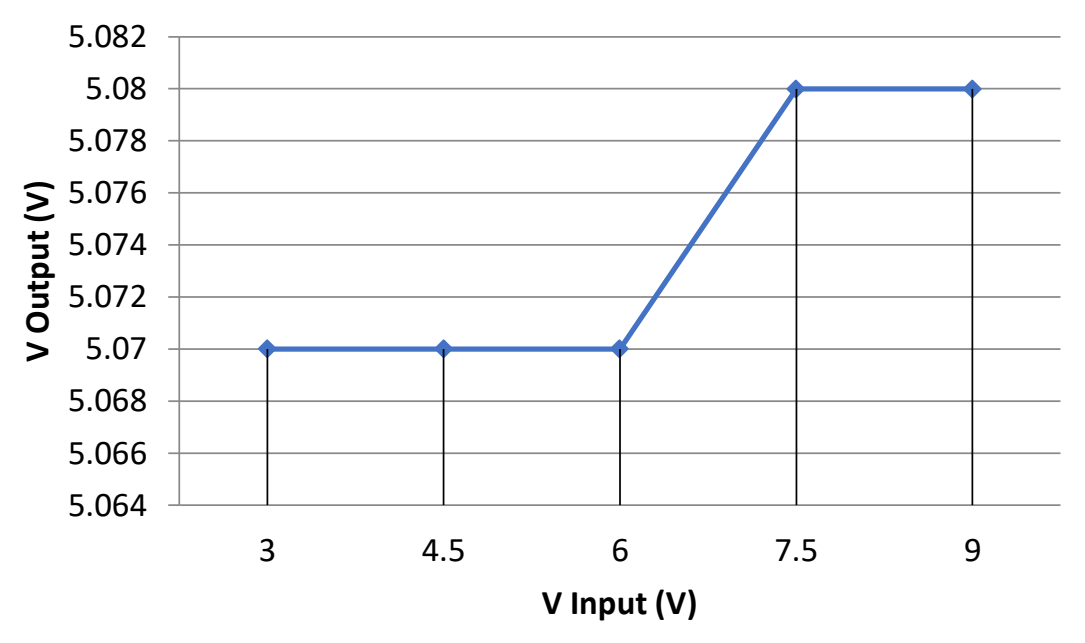

Gambar 3. Grafik Hubungan Antara V Input dan V Output pada Pengujian Pertama

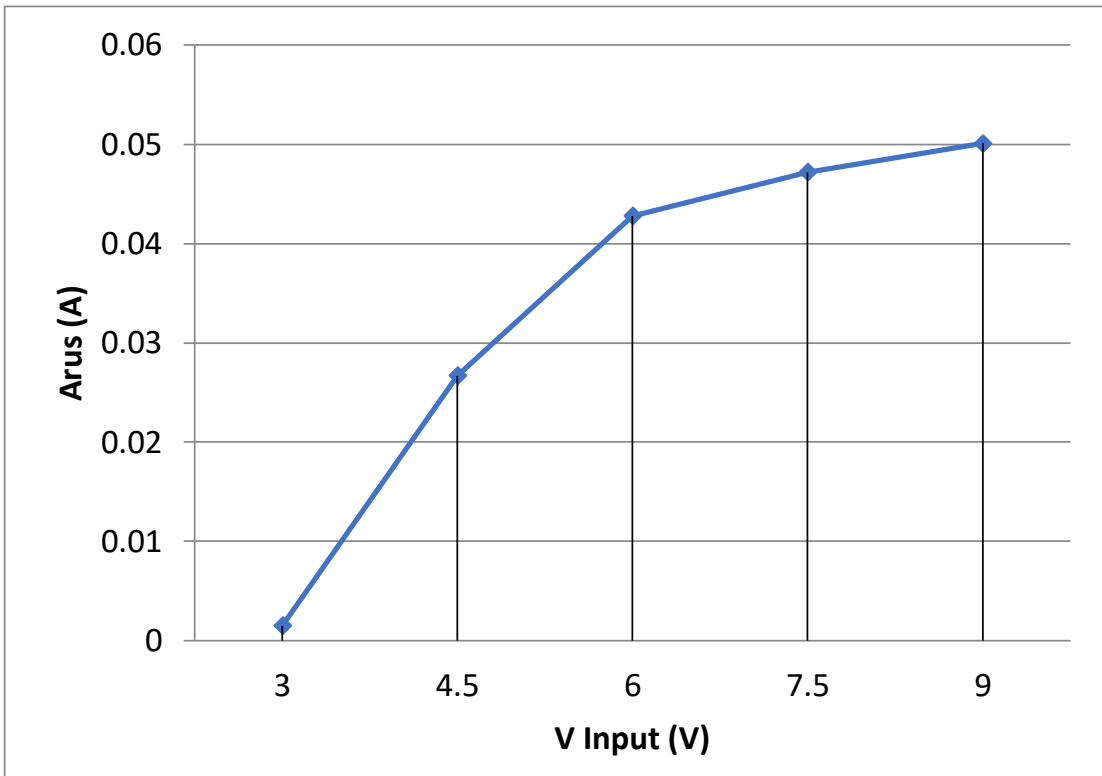

Gambar 4. Grafik Hubungan Antara V Input dan Arus pada Pengujian Pertama

Dengan menggunakan rumus persentase nilai error dalam Persamaan 1. Didapatkan persentase nilai error tegangan output sebesar 1,45\%, sehingga memiliki persentase ketepatan sebesar $98,55 \%$. Untuk mendapatkan nilai standar deviasi dapat menggunakan rumus pada Persamaan 2.

$$
\begin{gathered}
\% \text { error }=\frac{\text { Mean Nilai Terbaca }- \text { Nilai Sebenarnya }}{\text { Mean Nilai Terbaca }} \times 100 \% \\
\text { Standar Deviation }=\sqrt{\frac{\sum(x-\text { mean } x)^{2}}{(n-1)}}
\end{gathered}
$$

Sehingga didapatkan nilai standar deviasi/penyimpangan besar arus yang dihasilkan sebesar 0,009 , karena nilai ini terlampau sangat kecil $(<1)$, dapat dipastikan bahwa data yang dihasilkan bersifat akurat dan hanya mengalami sedikit penyimpangan data. 


\subsection{Pengujian Kinerja Rangkaian Pembangkit Termoelektrik}

Dalam Tabel 2, Gambar 5, Gambar 6, dan Gambar 7 menunjukkan data hasil pengujian kedua, dimana terjadi perubahan tegangan, arus dan indikator berupa nyala lampu yang dihasilkan saat terjadi berbagai perubahan delta suhu $(\Delta T)$.

Tabel 2. Data Hasil Percobaan Kinerja Rangkaian Pembangkit Termoelektrik

\begin{tabular}{ccccccccc}
\hline No. & $\begin{array}{c}\text { Pendingin } \\
\left({ }^{\circ} \mathrm{C}\right)\end{array}$ & $\begin{array}{c}\text { Pemanas } \\
\left({ }^{\circ} \mathrm{C}\right)\end{array}$ & $\Delta \mathrm{T}\left({ }^{\circ} \mathrm{C}\right)$ & $\operatorname{Vin}(\mathrm{V})$ & $\begin{array}{c}\text { Vout } \\
(\mathrm{V})\end{array}$ & $\begin{array}{c}\text { Arus } \\
(\mathrm{A})\end{array}$ & $\begin{array}{c}\text { Daya } \\
(\mathrm{W})\end{array}$ & Lampu \\
\hline 1. & 15 & 27 & 12 & 0,92 & 0,90 & 0,0017 & 0,0015 & Mati \\
\hline 2. & 15 & 45 & 30 & 2,57 & 2,50 & 0,0346 & 0,0865 & Nyala \\
\hline 3. & 15 & 50 & 35 & 2,66 & 2,63 & 0,0402 & 0,1057 & Nyala \\
\hline 4. & 15 & 55 & 40 & 2,68 & 2,68 & 0,0496 & 0,1329 & Nyala \\
\hline 5. & 15 & 60 & 45 & 2,88 & 2,84 & 0,0529 & 0,1502 & Nyala \\
\hline 6. & 15 & 65 & 50 & 3,05 & 3,04 & 0,0601 & 0,1827 & Nyala \\
\hline 7. & 15 & 70 & 55 & 3,07 & 3,06 & 0,0622 & 0,1903 & Nyala \\
\hline 8. & 15 & 75 & 60 & 3,19 & 3,15 & 0,0742 & 0,2337 & Nyala \\
\hline 9. & 15 & 80 & 65 & 3,29 & 3,23 & 0,0783 & 0,2529 & Nyala \\
\hline 10. & 15 & 85 & 70 & 3,40 & 3,39 & 0,0803 & 0,2718 & Nyala \\
\hline
\end{tabular}

Pada Tabel 2 dapat dianalisis bahwa ketika diberikan beberapa $\Delta T$ yang berbeda pada pembangkit termoelektrik akan menghasilkan tegangan, arus, dan daya yang bervariasi pula. Tentunya, hal ini sesuai dengan penelitian (Benof Arya, 2015). Pada pengukuran tegangan masukan, Probe Avometer diletakkan pada keluaran dari pembangkit termoelektrik dan pada konektor untuk mengukur tegangan keluaran. Kabel antara pembangkit termoelektrik dan konektor dihubungkan secara langsung tanpa adanya rangkaian penstabil, sehingga seharusnya nilai tegangan masukan dan keluaran bernilai sama. Namun, pada pengujian nilai tersebut mengalami sedikit perbedaan sekitar 0,01 hingga $0,06 \mathrm{~V}$, tegangan inilah yang disebut sebagai Voltage Drop atau tegangan yang hilang dalam suatu penghantar.

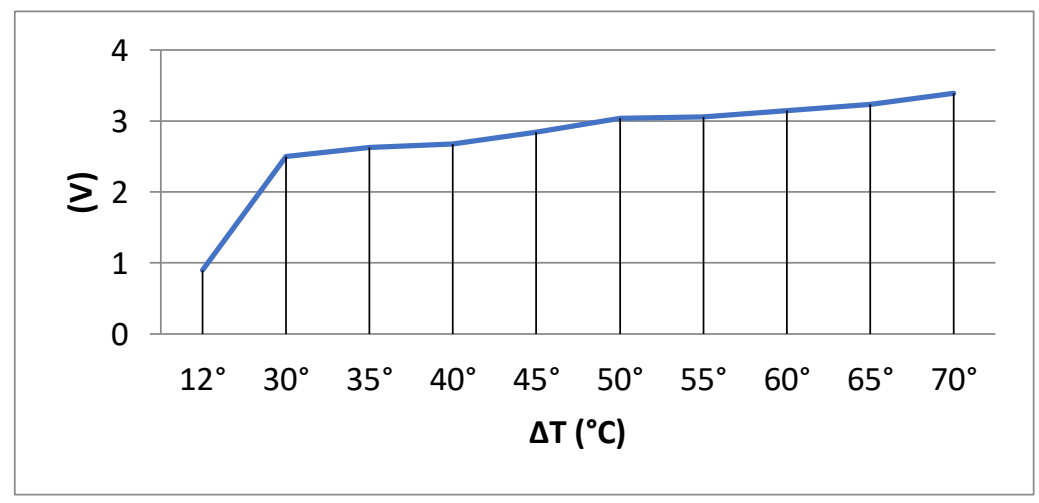

Gambar 5. Grafik Hubungan Antara $\Delta t$ dan V Output pada Pengujian Kedua

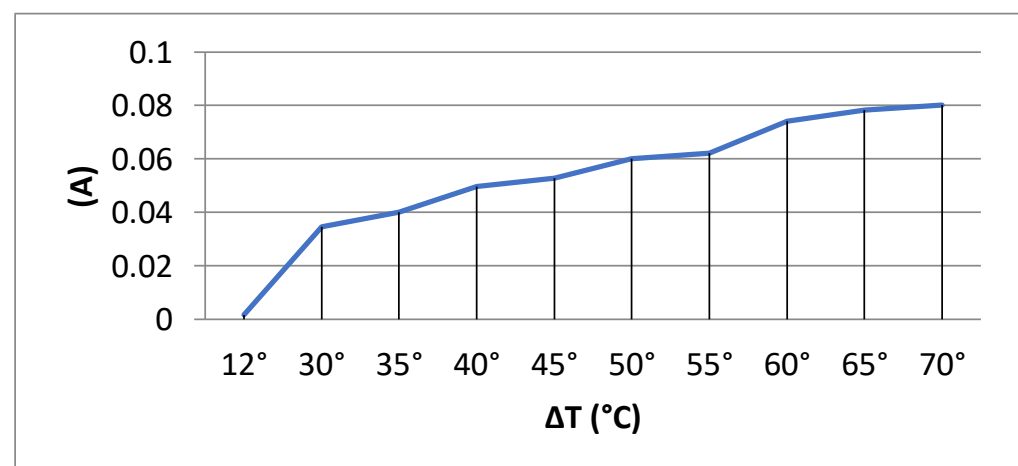

Gambar 6. Grafik Hubungan Antara $\Delta t$ dan Arus pada Pengujian Kedua

Rancang Bangun Penstabil Tegangan..., Ailin Rohmatul Fajria, Budhi Priyanto, Ilham Pakaya, 


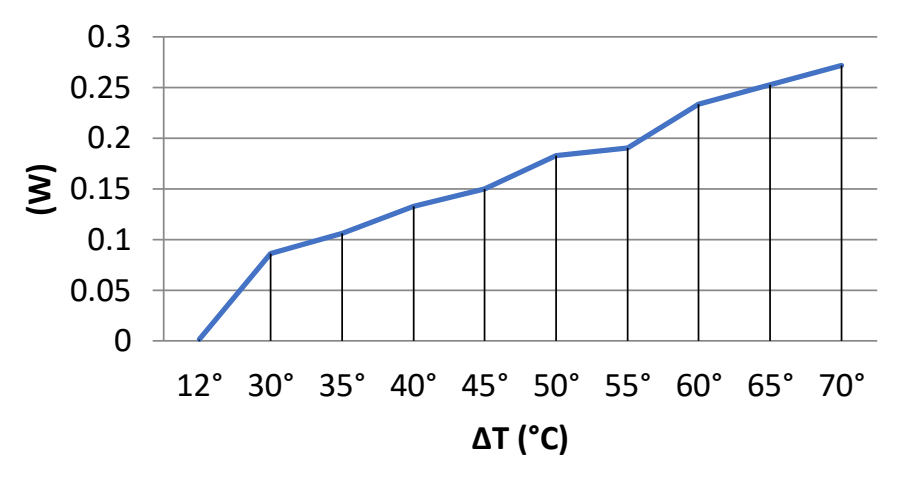

Gambar 7. Grafik Hubungan Antara $\Delta t$ dan Daya pada Pengujian Kedua

Untuk dapat mencari nilai persamaan dan relasi variabel data yang ditunjukkan pada Gambar 5 hingga Gambar 7, dapat menggunakan Persamaan 3 hingga Persamaan 6.

$$
\begin{gathered}
y=a+b \Delta x \\
a=\frac{(\Sigma \mathrm{y})\left(\Sigma \mathrm{x}^{2}\right)-(\Sigma \mathrm{x})(\Sigma \mathrm{xy})}{\mathrm{n}\left(\Sigma \mathrm{x}^{2}\right)-(\Sigma \mathrm{x})^{2}} \\
b=\frac{\mathrm{n}(\Sigma \mathrm{xy})-(\Sigma \mathrm{x})(\Sigma \mathrm{y})}{\mathrm{n}\left(\Sigma \mathrm{x}^{2}\right)-(\Sigma \mathrm{x})^{2}} \\
R=\frac{\sum x y-\frac{\sum x \sum y}{n}}{\sqrt{\left[\sum x^{2}-\frac{\left(\sum x\right)^{2}}{n}\right]\left[\sum y^{2}-\frac{\left(\sum y\right)^{2}}{n}\right]}}
\end{gathered}
$$

Sehingga didapatkan persamaan $y=0,87+0,03 x$ dan $R=0,955$, $y=-0,0123+0,0011 x$ dan $\mathrm{R}=0,99, \mathrm{y}=-0,067+0,0041 \mathrm{x}$ dan $\mathrm{R}=0,98$, pada tiap variabel dalam Gambar 5 hingga Gambar 7. Nilai relasi (R) menunjukkan nilai positif dan mendekati nilai 1 yang berarti memiliki relasi yang berbanding lurus, semakin besar nilai variabel $x$ maka semakin besar pula nilai variabel $y$.

\subsection{Pengujian Rangkaian Penstabil Menggunakan Sumber Pembangkit Termoelektrik}

Dalam Tabel 3, Gambar 8 hingga Gambar 10 menunjukkan data hasil pengujian ketiga, dimana terjadi perubahan tegangan, arus dan indikator berupa nyala lampu yang dihasilkan saat terjadi berbagai perubahan delta suhu $(\Delta \mathrm{T})$.

Tabel 3. Data Hasil Percobaan Rangkaian Penstabil menggunakan Pembangkit Termoelektrik No. Pendingin Pemanas $\Delta \mathrm{T}\left({ }^{\circ} \mathrm{C}\right) \quad$ Vin $(\mathrm{V}) \quad$ Vout Arus Daya Lampu

\begin{tabular}{ccccccccc} 
& $\left({ }^{\circ} \mathrm{C}\right)$ & $\left({ }^{\circ} \mathrm{C}\right)$ & & & $(\mathrm{V})$ & $(\mathrm{A})$ & $(\mathrm{W})$ & \\
\hline 1. & 15 & 27 & 12 & 0,82 & 0,80 & 0,0009 & 0,0007 & Mati \\
\hline 2. & 15 & 45 & 30 & 2,59 & 5,08 & 0,0341 & 0,1732 & Nyala \\
\hline 3. & 15 & 50 & 35 & 2,70 & 5,08 & 0,0398 & 0,2021 & Nyala \\
\hline 4. & 15 & 55 & 40 & 2,71 & 5,08 & 0,0412 & 0,2092 & Nyala \\
\hline 5. & 15 & 60 & 45 & 2,84 & 5,09 & 0,0456 & 0,2321 & Nyala \\
\hline 6. & 15 & 65 & 50 & 3,10 & 5,09 & 0,0479 & 0,2438 & Nyala \\
\hline 7. & 15 & 70 & 55 & 3,12 & 5,08 & 0,0498 & 0,2529 & Nyala \\
\hline 8. & 15 & 75 & 60 & 3,19 & 5,09 & 0,0512 & 0,2606 & Nyala \\
\hline 9. & 15 & 80 & 65 & 3,28 & 5,08 & 0,0531 & 0,2697 & Nyala \\
\hline 10. & 15 & 85 & 70 & 3,45 & 5,09 & 0,0542 & 0,2758 & Nyala \\
\hline
\end{tabular}


Tabel 3 dapat dianalisis bahwa secara umum, rangkaian penstabil yang dipasang pada pembangkit termoelektrik telah berfungsi dengan baik yang dapat bekerja bila tegangan masukan memenuhi tegangan cut off rangkaian penstabil yaitu $2 \mathrm{~V}$. Pada pengukuran tegangan masukan, probe avometer diletakkan pada keluaran dari pembangkit termoelektrik dan pada konektor output rangkaian penstabil untuk mengukur tegangan keluaran. Tegangan keluaran telah mengalami proses stabilisasi sehingga nilai tegangan keluaran bernilai stabil pada $5 \mathrm{~V}$ meskipun tegangan masukannya berubah-ubah. Namun, pada pengujian ini nilai tegangan keluaran tidak dapat bernilai tepat pada $5 \mathrm{~V}$, ada selisih nilai 0,08 hingga $0,09 \mathrm{~V}$. Hal ini disebabkan oleh beberapa faktor, seperti adanya tegangan drop, maupun pengukuran yang tidak presisi.

Dengan menggunakan Persamaan 3 hingga Persamaan 6, didapatkan persamaan 7. pada tiap variabel dalam Gambar 8 hingga Gambar 10. Nilai relasi (R) menunjukkan nilai positif dan mendekati nilai 1 yang berarti memiliki relasi yang berbanding lurus, semakin besar nilai variabel $\mathrm{x}$ maka semakin besar pula nilai variabel $\mathrm{y}$.

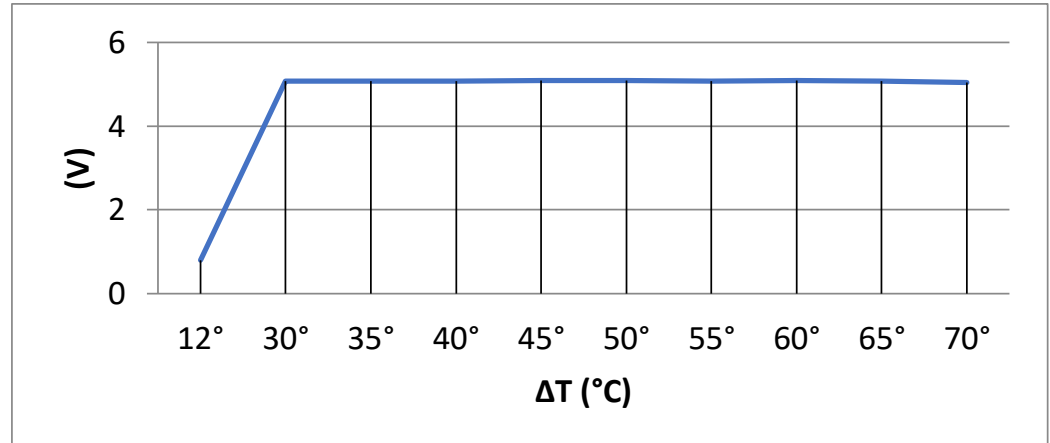

Gambar 8. Grafik Hubungan Antara $\Delta t$ dan v Output pada Pengujian Ketiga

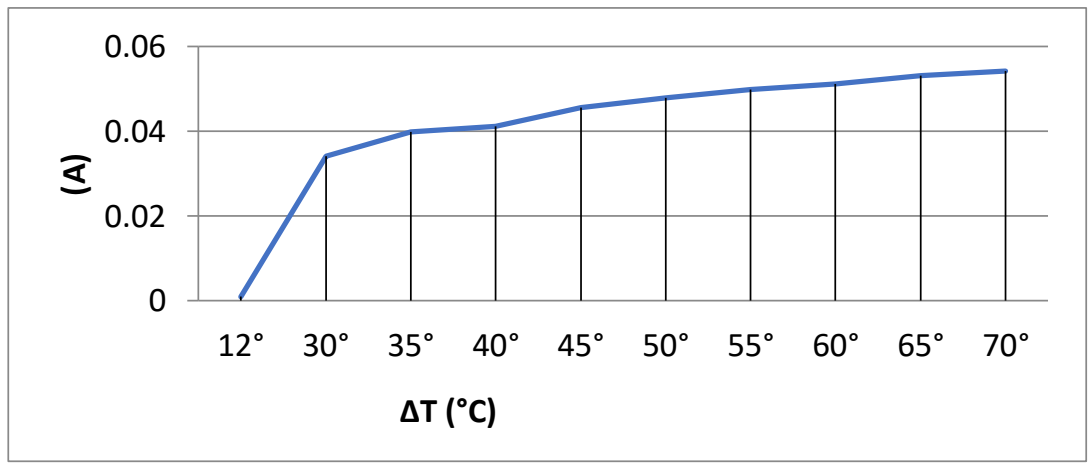

Gambar 9. Grafik Hubungan Antara $\Delta t$ dan Arus pada Pengujian Ketiga

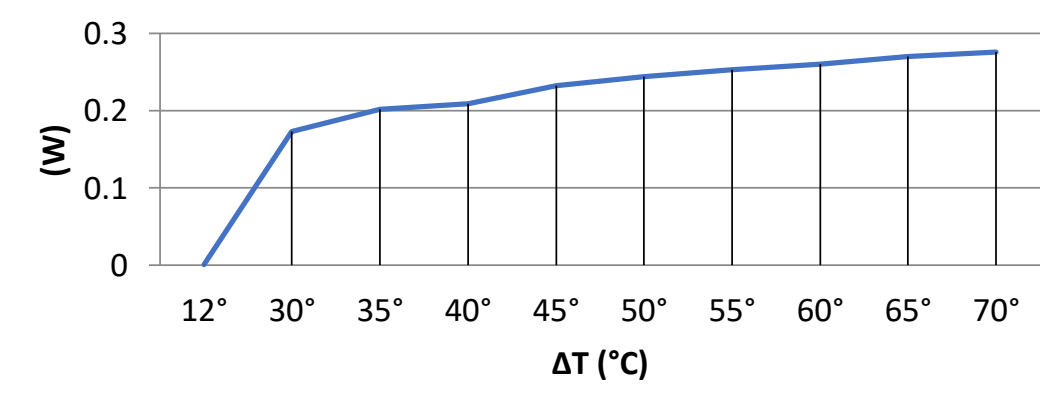

Gambar 10. Grafik Hubungan Antara $\Delta t$ dan Daya pada Pengujian Ketiga

$$
\begin{gathered}
\mathrm{y}=1,79+0,051 \mathrm{x} \text { dan } \mathrm{R}=0,76, \mathrm{y}=0,0003+0,0007 \mathrm{x} \text { dan } \mathrm{R}=1, \mathrm{y} \\
=-0,015+0,0038 \mathrm{x} \text { dan } \mathrm{R}=1
\end{gathered}
$$

Rancang Bangun Penstabil Tegangan..., Ailin Rohmatul Fajria, Budhi Priyanto, Ilham Pakaya, 


\section{Kesimpulan}

Berdasarkan hasil pengamatan uji coba alat, pengolahan dan analisis data yang telah dilakukan maka dapat disimpulkan bahwa sistem rangkaian penstabil memiliki tegangan kerja 2 hingga $24 \mathrm{~V}$ sesuai dengan datasheet komponen penstabil yang digunakan. Pada saat tidak menggunakan penstabil, tegangan keluaran mengikuti nilai tegangan masukan karena tanpa mengalami proses yang ada pada rangkaian penstabil, yaitu booster dan voltage divider. Saat menggunakan penstabil tegangan, tegangan masukan diproses oleh rangkaian hingga mengeluarkan tegangan stabil pada $5 \mathrm{~V}$, meskipun tegangan masukan yang diberikan berada dibawah maupun diatas tegangan yang diharapkan. Pada pengujian rangkaian penstabil menggunakan adaptor, tegangan keluaran yang dihasilkan memiliki persentase ketepatan $98,55 \%$ dan error $1,45 \%$, arus yang dihasilkan dari beberapa pengujian memiliki standar error dan deviasi yang lebih kecil dari nilai Mean arus.

Pada pembangkit termoelektrik tanpa menggunakan penstabil hubungan antara $\Delta \mathrm{T}$ dan $\mathrm{V}$ memiliki persamaan $\mathrm{y}=0,87+0,03 \mathrm{x}$ dan $\mathrm{R}=0,955$, antara $\Delta \mathrm{T}$ dan I memiliki persamaan $\mathrm{y}=$ $-0,0123+0,0011 \mathrm{x}$ dan $\mathrm{R}=0,99$, dan antara $\Delta \mathrm{T}$ dan $\mathrm{P}$ memiliki persamaan $\mathrm{y}=-0,067+0,0041 \mathrm{x}$ dan $\mathrm{R}=0,98$. Pada pembangkit termoelektrik dengan menggunakan penstabil hubungan antara $\Delta \mathrm{T}$ dan $\mathrm{V}$ memiliki persamaan $\mathrm{y}=1,79+0,051 \mathrm{x}$ dan $\mathrm{R}=0,76$, antara $\Delta \mathrm{T}$ dan I memiliki persamaan $\mathrm{y}=0,0003+0,0007 \mathrm{x}$ dan $\mathrm{R}=1$, kemudian antara $\Delta \mathrm{T}$ dan $\mathrm{P}$ memiliki persamaan $\mathrm{y}=$ $-0,015+0,0038 \mathrm{x}$ dan $\mathrm{R}=1$.

1. Pada seluruh hasil pengujian, $R$ bernilai positif yang berarti berbanding lurus, semakin besar nilai variabel $\mathrm{X}$ maka semakin besar pula nilai variabel $\mathrm{Y}$.

\section{Daftar Notasi}

$$
\Delta^{\circ} \mathrm{T} \text { : delta suhu }
$$

\section{Referensi}

[1] P. Patil and P. Patil, "Review on Thermoelectric Devices," Int. Journal Of Emerging Technology And Advanced Engineering (IJETAE), Vol. 3, No. 10, Pp. 681-687, 2013.

[2] S. Khode, P. Kale, and C. Gandhile, "Review on Application of Thermoelectric Peltier Module in cooling and power generating Technology," Int. Journal Of Engineering And Technical Research (IJETR), Vol. 3, No. 1, Pp. 71-74, 2015.

[3] S. Wardoyo, R. Munarto, and V. Putra, "Rancang Bangun Data Logger Suhu Menggunakan Labview," Jurnal Ilmiah Elite Elektro, Vol. 4, No. 1, Pp. 23-29, 2013.

[4] R. Umboh, J. Wuwung, and E. Allo, "Perancangan alat pendinginan portable menggunakan elemen peltier," Universitas Sam Ratulangi, 2014.

[5] R. S. Alexander Wijaya, Pengaruh Rangkaian Seri-Paralel Sel Peltier Dan Beda Temperatur Terhadap Daya Listrik Yang Dihasilkan Sel Peltier. Universitas Brawijaya, 2015.

[6] E. Sukur, Melirik Teknologi Termoelektrik Sebagai Sumber Energi Alternatif. 2011.

[7] G. Levy, "Thermoelectric Effect Under Adiabatic Condition," Entropy Journal, Vol. 14, No. 71, 2013.

[8] I. D. . Ramdini, "Thermoelectric Generator," Indonesian Journal of Material Science, Vol. 47, No. 120, 2014.

[9] F. J. Bueche, Fisika Universitas, Edisi Kese. Jakarta: Erlangga, 2006.

[10] A. W. Ulp, Prinsip-Prinsip Konversi Energi. Jakarta: Erlangga, 1996. 